\title{
Clothing for the College Girls from the Victorian Days to the 1940s
}

\author{
Miku Hirata \\ Graduate School of Human Sciences and Design, Japan Women's University, Tokyo, Japan
}

\section{Email address:}

mikuhirata70@gmail.com

\section{To cite this article:}

Miku Hirata. Clothing for the College Girls from the Victorian Days to the 1940s. American Journal of Art and Design.

Vol. 5, No. 2, 2020, pp. 28-38. doi: 10.11648/j.ajad.20200502.12

Received: June 8, 2020; Accepted: June 30, 2020; Published: July 13, 2020

\begin{abstract}
The paper provides an insight regarding the clothing for college girls from the Victorian days to the 1940s. It elaborates on game wears, clothing for tea and cocoa parties, evening dresses, and academic dresses while taking into consideration the degree being pursued. The primary sources for information are their autobiographies, memoirs, diaries, letters, and other records. Upon studying these records a few factors are evident. College girls attempted to cope with 'double conformity', that is, two standards, 'to study better than the men' and 'to be ladylike'. However, these often could not be achieved together. They managed to address this by first changing dark day dresses into beautiful evening dresses, and second, by wearing academic dresses with triangular soft caps which demonstrated both their professionalism and seriousness of purpose and their femininity. Furthermore, clothes played an important role in indicating their identity. While participating in sports, game wear had an important role in displaying solidarity and promoting a sense of belonging to their own team or college. When the ceremonies such as evening and tea parties were held, they wore special dresses for the parties to display a sense of participation in their community.
\end{abstract}

Keywords: College Girls, Game Wear, Evening Dress, Academic Dress, Identity

\section{Introduction}

\subsection{Purpose}

This paper provides an insight regarding the attempt made by college girls to establish their identity through clothes from the Victorian era to the 1940s. Game wear, evening dresses, and academic dresses have been taken into consideration.

\subsection{Colleges for Study}

Seven colleges have been included in this study as these were established in the nineteenth century and became pioneers of tertiary education for women. These colleges were established for women in the Victorian period and include, Girton and Newnham, Cambridge; Somerville, Lady Margaret Hall, St. Hilda's College and St. Hugh's College, Oxford; and the Royal Holloway College, the University of London.

\subsection{Earlier Studies}

Women's college have been previously discussed in the history of women's education, especially from the historical context of feminism and gender. Regarding the ideal images of girls and their education, Deborah Gorham discussed the ideology, education and how they changed according to the period. [1] Carol Dyhouse, in her book, examined the experiences of teachers and students in colleges before 1939. [2] Additionally, Briony Kay discussed the creation of a feminine university and the education at Royal Holloway in her dissertation. She elaborates that between 1886 and 1914, the college tried to establish both, the traditional femininity and the academic successes. [3]

In an article, Sara Delamount discussed, 'The central theme that can be traced through the establishment of education for middle and upper class girls and women from the 1840s until the present day is double conformity.' According to her, 'This double conformity, a double bind or catch 22 , requires strict adherence on the part of both educators and educated to meet two sets of rigid standards, those of ladylike behaviour at all times and dominant male cultural and educational systems.' [4]

Muriel C. Bradbrook, in her centenary history of Girton College, Cambridge described how Emily Davies, the founder, 
enforced double conformity on her students. This implied that, 'Young ladies were to behave like young ladies, while at the same time they were to omit nothing, absolutely nothing, from their course of study which was required of [the male] undergraduates.' [5]

Historians have pointed out that it was difficult for young ladies to balance one rigid standard with the other. If they attempted to 'behave like ladies', they often had to omit something from the study course which male students took. If they wanted to study as hard as or harder than male students, they were liable to forget to behave in a ladylike manner. Consequently, they were often stuck in a real double bind.

From a brief survey of these earlier studies a few questions arise that would be addressed in this paper. Although these elaborate on girl's college and the students from several view-points, very few studies are available regarding the clothes of college girls. The notable exception is Jane Robinson, who discussed 'fashion' which 'played a significant part in' college girls' lives in her book, one of the most important literatures on history of women's colleges and their college girls. [6] However, even she does not ask the following questions. What are the kinds of clothes that they wore and what thoughts did they express through their clothing? Particularly, the double conformity discussed by Sara Delamount, as a central theme related to education for girls, should be considered as an important issue. How did college girls address this double conformity and how did they try to overcome it? What were their experiences related to this and were they reflected in their clothing?

\subsection{Material}

This paper bases its analysis on the following material and also takes these earlier studies into account. First, it uses the reminiscences and memoirs of graduates who studied at women's college from the Victorian era to the first half part of the twentieth century. This includes autobiographies and memoirs that were recorded by the individuals. John Tosh suggests that, 'autobiographies may be very revealing of mentality and values', as they are based on individual's emotions and life. [7]

Second, this paper takes into account diaries and letters and attempts to access information regarding the lives and clothing of college girls. These record sources are called 'confidential documents', 'self-narratives' or 'ego-documents' and 'it is in these forms that men and women record their decisions, discussions and sometimes their innermost thoughts, unmindful of the eyes of future historians.' [7]

Third, recorded interviews from St. Hilda's have also been studied. Over time, using the 'real voice' as a historical source has attracted attention. [8] Lou Taylor suggests that 'the essence of oral history is that it can catch hold of people's memories through their own voices, a quality that is especially relevant for those marginalised by or excluded from 'big' history.' [8]

Lastly, other than these, college magazines, school histories, photographs, and surviving costumes including, game wear, uniforms, college ties and academic dresses have been used.
These materials are important sources to study the lives and clothes of college girls during that period. Furthermore, local and national newspapers are also included as these are traditional and important sources of information.

In his book about nineteenth century outfits for men, Christopher Breward elaborates on how he brought together different sources to study the dresses and refers to this as 'splicing together different classes of evidence.' [9] Based on his suggestion, this paper also examines dresses by 'splicing together' these different sources of information.

\section{Clothing for the College Girls from the Victorian Days to the 1930s}

\subsection{Ordinary Clothes as Game Wear for Tennis}

From the 1850 s to the 1920 s, male undergraduates at Oxbridge 'continues to be associated with masculine privilege, exclusively, and male elitism'. In comparison, college girls were always considered as outsiders. At the Oxbridge women's colleges, dons and students adopted a plain, austere style of dressing to demonstrate their professionalism and seriousness of purpose. This was originally also worn for games. [10] Kathleen McCrone studied the ordinary dresses and game wear for college girls, including the dress reforms in the Victorian days, by gathering information from college magazines. [11]

In terms of ordinary clothes, at Cambridge, the clothing was very sombre. Eva, a student at Girton in 1883 mentions that her friend 'wore a long black robe and over it another flowing garment of white edged with black, her long slender arms looking very white indeed among all this sombre array.' [12] In addition, items such as gloves and hats were also a part of the clothing. Elizabeth Maclead received a scholarship for Girton and began studying here in 1881. In her record, 'A Day at Girton,' she states that, 'I was in the era of such regulation as "draped to-the-knee" and that "On Sunday, we are all particularly respectably [sic], in hats and gloves and so on... while on other days we wear little red caps with tassels like night-caps.' [13] These items were also a part of conventional Victorian feminine dress, and it is a possibility that women might have been viewed as being unrespectable if they were seen without these items.

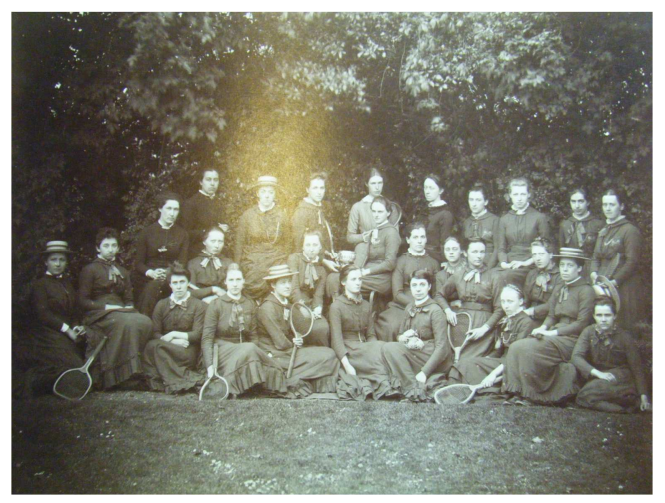

Figure 1. Tennis Team, 1885, Newnham College. 
In those days, college girls were only permitted to play tennis as a sport. This was largely because femininity could be maintained while playing tennis and it could be played in ordinary clothing. Figure 1 is a collective photograph of tennis players in Newnham College in 1885.

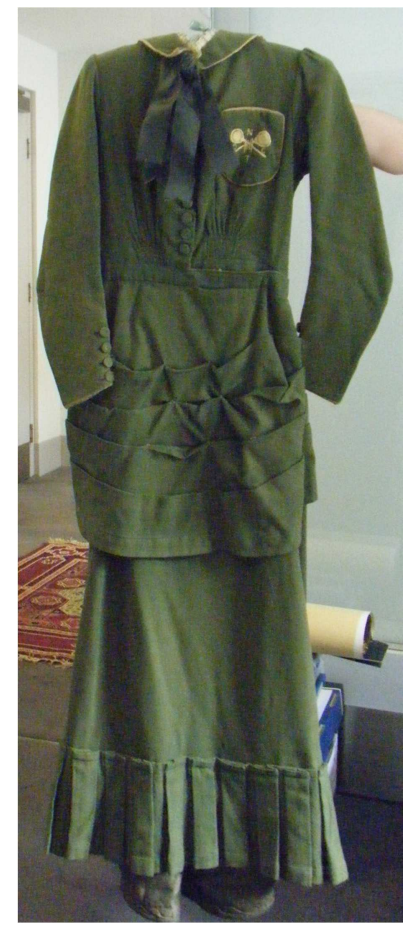

Figure 2. Tennis Dress (1885).

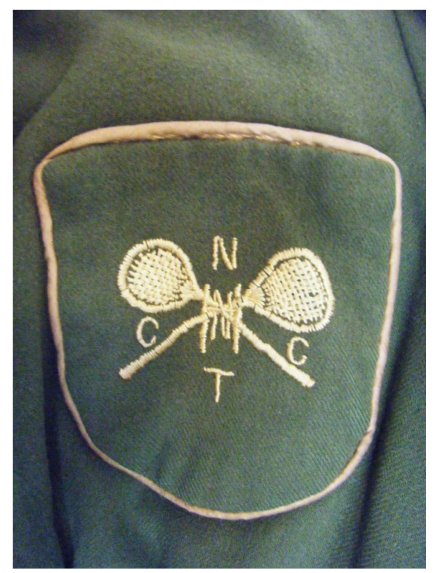

Figure 3. NTC, Initials.

It can be seen from a surviving costume of the tennis dress in 1885 (Figure 2) that the girls wore the bustle style dress which was considered fashionable in the 1880 s and that the long jacket had (four) pleated layers. Figure 3 shows the breast pocket had the shape of a tennis racket and NTC embroidered on it, which were the initials of the Newnham Tennis Club. A student who attended the tennis match between Oxford and Cambridge on the $3^{\text {rd }}$ of July, 1886, said that this was 'the prettiest costume.' [14] Attending such inter-collegiate matches by wearing the same clothing considerably strengthened their sense of belonging to their own team or college. [15]
Into the $1890 \mathrm{~s}$, college girls began to wear a combination of skirts, blouses, hats, and ties. This clothing can be seen in the photographs of sports teams. Figure 4 is a photograph of the members of St Hilda's college in 1899. One of the members is holding a tennis racket. Figure 5, shows a dark blue tie with thin yellow stripes and white stripes that was worn by Miss Burrows around 1900. Miss Borrow was the first principal of St. Hilda's and, as a university archivist said, 'the epitome of this ladylike approach.' [16] Figure 6 shows a dark blue tie with broad pale blue stripes and a thin white strap. This was first used for hockey and later as a college tie.

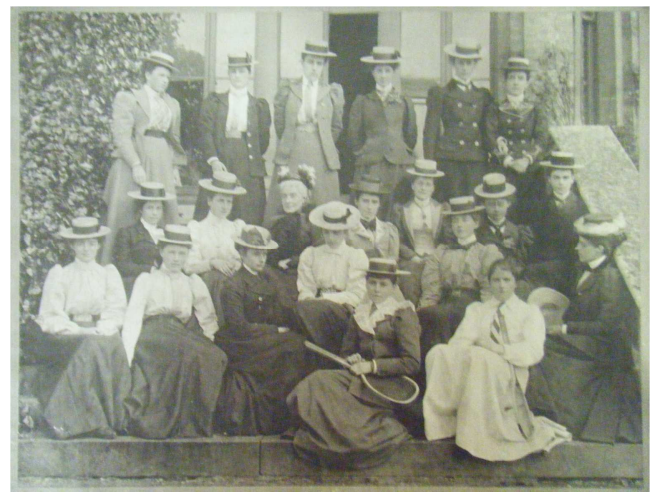

Figure 4. 1899 St. Hilda’s College.

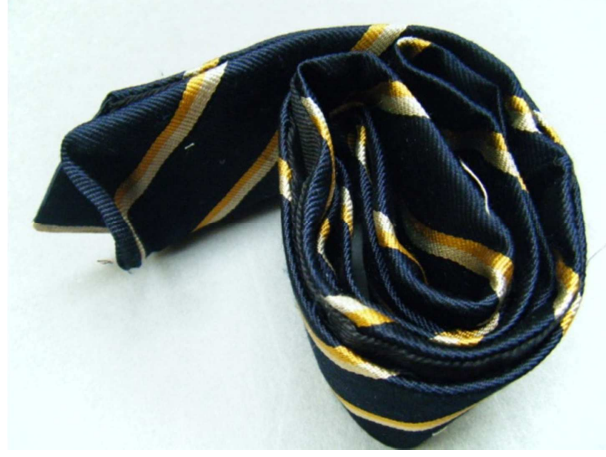

Figure 5. St. Hilda's College Tie.

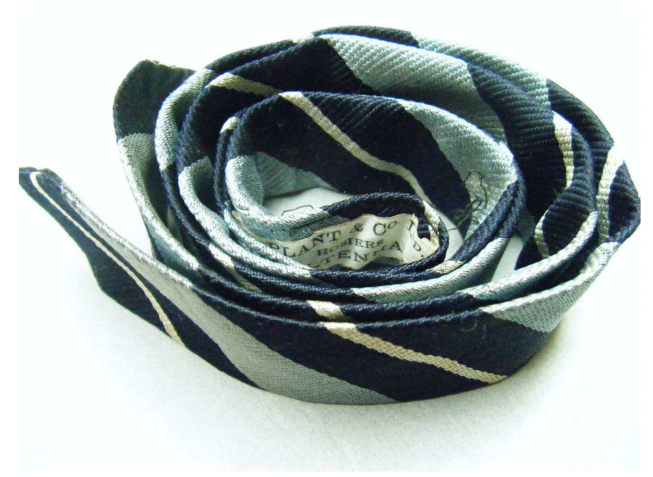

Figure 6. St. Hilda's College Tie.

The clothing for college girls reflects the environment of this period. It was not a uniform but a combination of skirts and blouses that was in style and was worn by women in general. Clothes for girls were required to be 'simple and sombre' and colleges ensured that this is practiced. [17] This 
practice was perhaps aimed at portraying femininity to the outside world, such as the men and the society, and to show a sense of solidarity to the inside world, such as the community for college girls.

\subsection{Clothes for Hockey and Boating}

Figure 7 is a picture of the jacket worn by the students of Royal Holloway from the 1910s to the 1930s. This jacket was mainly worn while playing hockey, lacrosse and viewing boat races. Figure 8 which was published on $17^{\text {th }}$ of January in 1922 in The Sphere, shows that college girls at Bedford College wore this jacket.

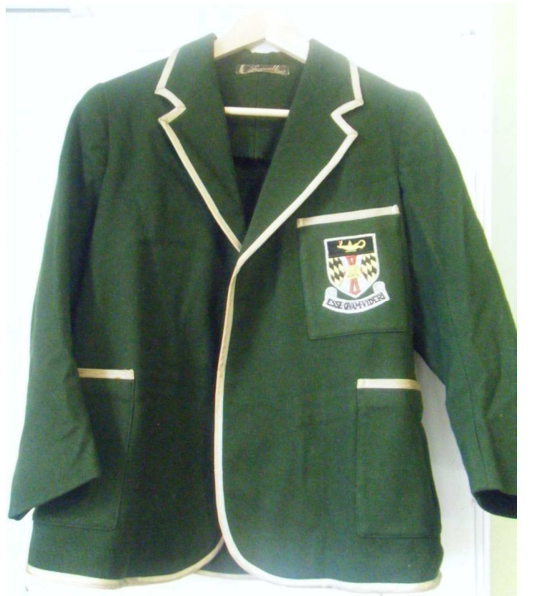

Figure 7. Tennis Jacket (1910s-1930s).

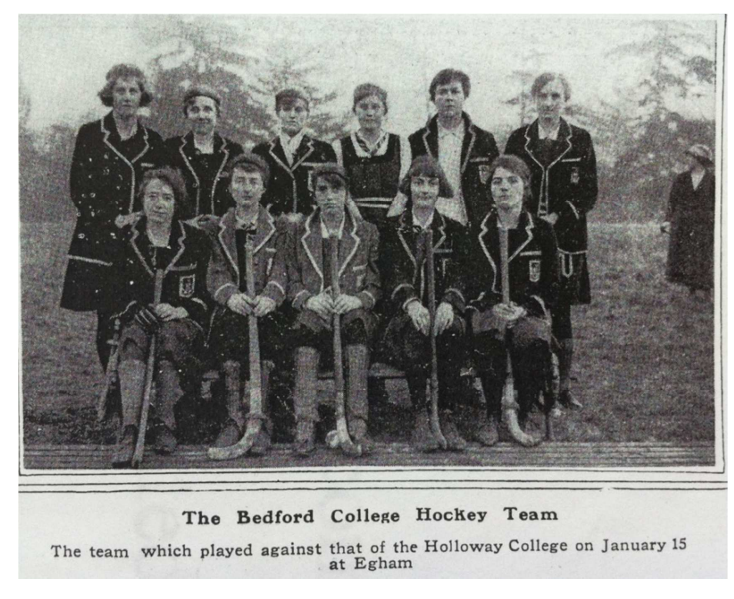

Figure 8. Sphere (1922).

The typical game costume for this period was the gym tunic and sailor suits for boating. Royal Holloway college girls wore the gym tunic in the 1900s.

I much enjoyed the weekly classes there taken by a visiting P.T. [Physical Training] specialist even though we had to wear skirts over our tunics, the latter reaching well to the knees, when going to and from the gymnasium, though we never encountered any man on the way. [18]

It seems that this girl was concerned about what men thought when they saw her. In the reminiscences in the 1910s, a student said, 'We are to wear gym-frocks, have our hair down, dance.' [19]
The gym tunic was also worn by students at Girton and Newnham college mainly when they played hockey. One of the students who studied at Girton College from 1923 to 1925 said, 'We wore stiff straw hats called boards with an olive-green ribbon and an ivy leaf badges along with a navy serge of skirt or gym-slip.' [20] She further elaborated, 'Gym-slips were sleeveless tunics of navy serge, with three box pleats on the front and back, set into a square yoke. The regulation length was such that' about 'two inches' fell on 'the ground when one knelt down.' [20] Another student said that it was a 'pleasure' 'to join the game period of hockey. In my ancient green tunic I could run fast enough to be occasionally of some use.' [21] The gym tunic worn by college girls was actually quite inconvenient for playing hockey as it slowed them down while running, but they wore it because it helped to maintain their femininity.

Besides the gym tunics, college girls of the St Hilda's boat club wore sailor blouses for boating (Figure 9). Boating was considered as an entertaining activity during college life and students of the Royal Holloway often practiced at River Thames. One student said, 'We wore so many clothes in those days... All in spotless white and with hats. It would have been 'not quite nice' to have been seen without one. We went sailing down the hill on our bicycles, and then bumped across the field.' [22]

Royal Holloway is located near River Thames and Butbridge reminisced, 'For most of us the great attraction was boating on the Thames at Egham... The clothes included ancient corsets, that were probably Victorian!' [23] As the years progressed, in the 1920s college girls began to wear new clothing for sports, but interestingly, Victorian corsets were still a part of the outfits. Just like hats and gloves were, corsets were also a part of conventional Victorian feminine dress and even in the 1920s women were probably not considered respectable if they were not wearing corsets. [24]

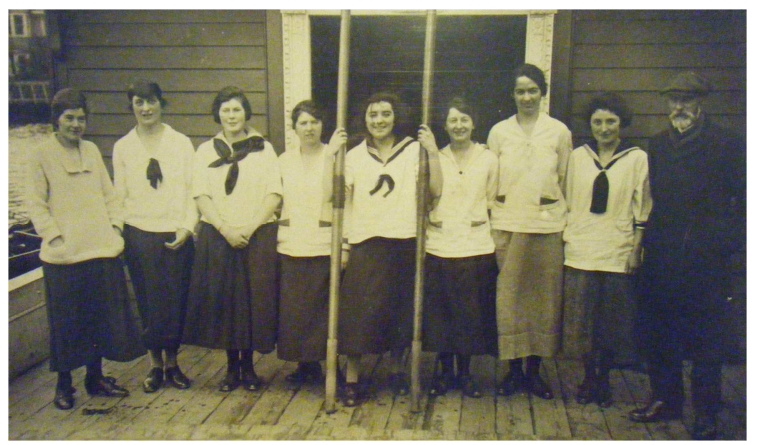

Figure 9. Rowing (St. Hilda's, 23, October, 1919).

\section{Clothing for the Afternoon and Evening Parties}

\subsection{Clothes for Cocoa and Tea Parties}

The custom of cocoa and tea parties that originated in the Victorian days was seen in the twentieth century as well. Cocoa parties were held before bedtime and tea parties were 
held in the afternoon. Figure 10 is a photograph of a tea party at Royal Holloway around the 1890s. Cocoa parties were considered fashionable in those days. The hostess would serve cocoa and the richest cakes available.

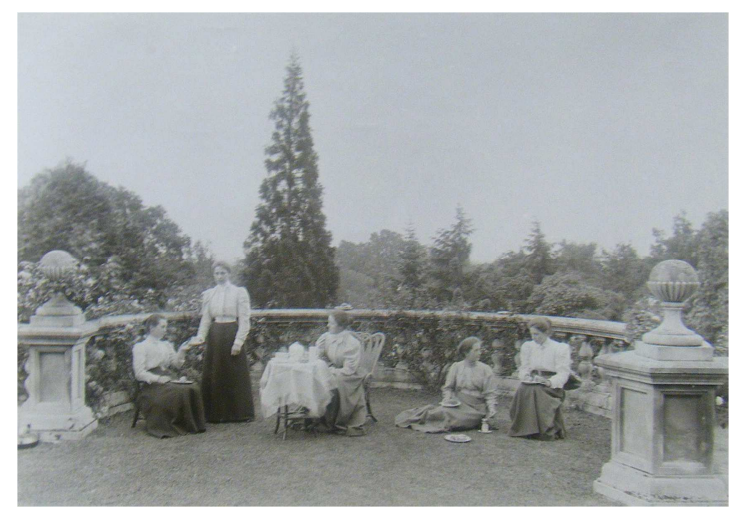

Figure 10. Tea Party, Royal Holloway College (1890s.).

Cocoa parties were a kind of social activity and were intended for a private community. [6] Even during the First World War, these parties were held in student rooms. 'We dressed in pyjamas \& dressing-gowns and sat in Miss Rawlinson's room while she was out somewhere else.... We behaved in almost disorderly fashion.' [19] 'Cocoa parties' were 'our private form of entertainment.' [23] Frances who was a student at St. Hilda's in the 1930s mentioned, 'Striking was, unfortunately, too strong a word to describe most of my wardrobe', and it also included 'sleeping apparel, made for me by my aunt from more odd bits and pieces.' [25] Her aunt made her pyjama based on her perception of Oxford life. Frances further elaborated,

She [Frances' aunt] drew her idea of what Oxford life must be from a study of the Society and Fashion page, and was, therefore, under the illusion that no ordinary nightdresses would be worn by my fellow students. Thus it was that I attended my first cocoa party in a black satin lounging pyjama.... [25]

The outfits for these cocoa parties were specially prepared. Although cocoa-parties were a special part of college lives, there were some students who could not attend these.

I had to stop going to evening coffee parties, because I could not offer similar ones, having no money to provide refreshments, and forbidding smoking in my room. But as our numbers were small I had to be included communal entertainments. [26]

She was worried about being excluded from the 'small' community.

Another student mentioned that, 'We had cocoa parties at night but didn't go very often because I was so sleepy...' but 'a lot of them were in pyjamas and dressing gowns and made a big fuss of cocoa and sticky buns and all sort of things.' [27] Finally, in the 1920s, 'Pyjamas began to be made for women, at first for little girls, then adults.' [28] Therefore, college women were more likely to wear pyjamas than other women. It can be stated that during this time while even trousers were not widely acceptable, pyjamas were leading the fashion and were perhaps considered as daring and also possibly posed a challenge to the perception of feminine dressing.

In addition to the cocoa and tea parties, college girls enjoyed garden parties on fine days. Figure 11 shows a garden tea party held in Girton in 1902 or 1903. College girls can be seen wearing white blouses and skirts that were considered fashionable at that time.

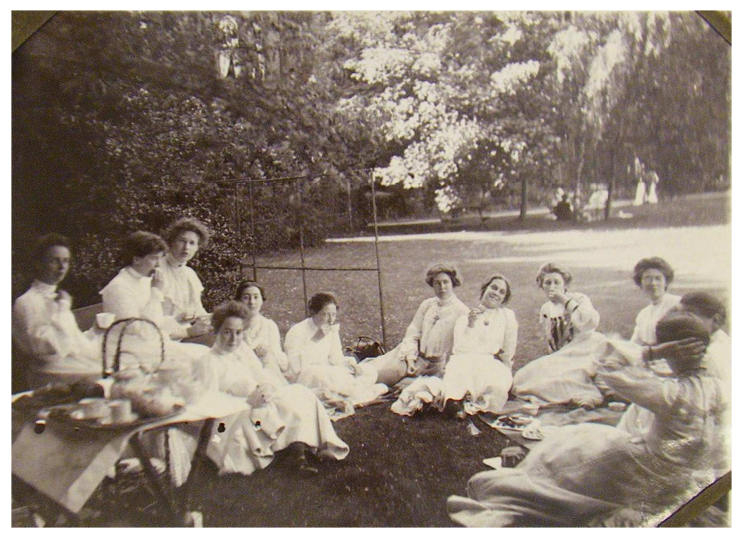

Figure 11. Garden Tea Party (1902-3).

Another Royal Holloway student said, 'I remember that I cycled down to Staines at the eleventh hour and bought the only one that would fit my large head' as 'we all had to have long garden party frocks (mine was home-made) and to wear hats' to attend the garden party. [29]

Each of these social gatherings played a vital role in communication, creating the requisite environment, and introducing fashionable clothing including night wear and hats. Dressing up for a garden party definitely created the feeling of a special occasion for the girls. Wearing pyjamas or dressing gowns for the cocoa parties probably created a sense of informality and the belief that they had created a social world for themselves that existed beyond the more formal world of college dinners.

\subsection{Evening Dress}

Evening dresses were worn for the evening meal and were seen from the latter part of the nineteenth century to the first half of the twentieth century. Alice Robinson described the evening dress in 1899 as below.

Dinner at $7 \mathrm{pm}$ was a formal occasion for which we changed into a simple kind of evening dress: if one had received an invitation to High Table, or perhaps to accompany the principal in the procession from library to the dining hall, that was an occasion for the best bit of tucker. [30]

In 1902, college girls wore the elegant line dress that was in fashion during the Edwardian days, as Alice reminisced, 'The first evening dress I had made for me was of black satin, with large puffed sleeves to the elbow and a skirt that billowed out to a train at the back (very inconvenient for dancing)' and it was 'trimmed pretty fully with deep cream lace.' [30]

At Royal Holloway in those days, the morning chapel and 
evening dinner were considered compulsory and dinner was more like a ritual, as one student said that 'True, morning chapel at 8 am was compulsory. We had to dress for dinner and assemble in the library, complete with a pre-arranged partner punctually at the given hour before walking in solemn procession the dining-hall.' [18]

The formal dinner which originated in the Victorian era and was ritualised in the Edwardian days, had become one of the most impressive events for students.

The custom of wearing evening dress continued until the First World War. However, some students could not buy evening dresses. Muriel Winifred recalled that, 'All my time at Cambridge I could never afford an evening dress as that was an expensive item'. She had stopped worrying about clothes years ago. [31]

During the war, at St. Hilda's College, it was established that wearing an evening dress was 'the rule for General Meetings. We also changed every evening, except on Sundays, for dinner and never appeared without stockings.' [32]

In the 1930s, as Morris mentioned, 'I had to take an evening dress and various other clothes,' [27] which implies that evening dresses were included as one of the required apparels for college life.

Patricia Garner who was at the Royal Holloway from 1931 to 1935 , recalled that when they heard the $7 \mathrm{pm}$ bell, they all changed into evening dresses, but 'Only those returning from inter-collegiate lectures or matches could get away with wearing day dresses and slip in at the end.' [33]

A letter from a student at Somerville College, mentions that in the beginning of the 1930s, 'At dinner the dean gave an absurd and lengthy speech on a subject dear to her heart, which was, dressing for dinner'. The dean stated, 'Old tradition, therefore good tradition. (some of students in the fourth year will remember this good old tradition)... This hall is the best modern hall in Oxford. Maids wait on us in a seemly fashion. Therefore, we should dress in a seemly fashion'. [34]

Another letter referred to the dean's decision about clothing for dinner, 'The dean ultimately issued' a directive 'on the subject of gown for dinner, having decided that gowns would not produce' the right effect befitting 'the beauty of hall and the solemn character of the meal. Therefore, we must change. (Note mostly [that] we didn't) Nuisance - but not really worth getting hot about.' [34]

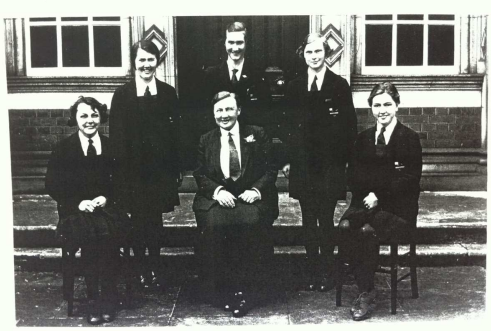

Figure 12. Miss Higgins with Her Students in 1933

These letters suggest that the dean wanted her students to 'dress in a seemly fashion' and that they did not follow the dean's final decision, and were hopeful that they would be able to keep wearing special and expensive clothing for dinner.

Another college educator, Miss Higgins (Figure 12), who was the principal of Royal Holloway from 1907 to 1935, also attempted to maintain the old tradition. There are many references about her clothing in the reminiscences of college girls. For example, during the 'day she was almost always dressed in a dark shirt with white blouse. Her skirts were ankle length. (After all, we ourselves were wearing our skirts at mid-calf length.) She had a strong and heavy tread and we used to smile among ourselves.' [35]

The dark shirt with a white blouse was the simple style which originated in the Victorian days. To maintain the tradition of the women's college, Miss Higgins wore the old-fashioned styles.

Although Miss Higgins wore simple and masculine styles during the day, for the evening she changed into more feminine dresses. Morris says that 'She [Miss Higgins] always wore beautiful evening dresses for dinner. She did not look masculine at all in the evening.' [27]

Another student recalled that 'In the evening she was transformed' as below.

The dresses she wore were obviously made specially for her, of some rich, silky material, both soft and unassuming in colour, having short sleeves above the elbow, with skirts that were both long and full till the ankles. With these dresses she always wore some heavy jewellery, as carefully chosen as the dresses. [35]

Miss Higgins shared the perspective about maintaining old tradition with the Sommerville's dean, but they were not in agreement regarding wearing 'beautiful' dresses for the evening meal. Students at Sommerville did not follow the dean's instructions and did not change their clothes for dinner, but students at Royal Holloway agreed with their principal's opinion.

Even during the Second World War, college girls continued to go out for formal dinners and wore evening dresses. Looking back to the beginning the War, one student said that the 'atmosphere' seemed to be rather 'Victorian', [36] 'Our partners' were 'arranged for at the beginnings of the term. Before dinner time' we changed into 'evening dress'. [36] As the war continued, this custom gradually faded.

The old custom of wearing long gowns and processing for dinner had almost been dispensed with, but still persisted during the summer term on Saturday or Sunday evenings. Some of us felt that it was a bit pretentious in the days of clothes rationing and insisted on wearing 'short' dresses even for the obligatory coffee with the principal or at the High Table. [37]

The custom to wear evening dresses was also seen at St Hilda's college. One of the students said that, 'Wartime evening dresses' were the pre-war 'dinner dresses, that is, elbow sleeves and no décolletage. This was a 1930s dress of pale blue flowered gauze over taffeta with a matching gauze 
jacket.' [38]

Wartime coupons made the clothing of college girls more restrictive. However, the delights of dressing still exited as below: 'The drabness of everyday wear further enhanced the delight of dressing up for special occasions: when I was ready for a dance, in my second-hand evening dress, my mother's jewelry and the silver sandals bought with precious coupons as well as money.' [39]

The custom to wear an evening dress continued even in the 1950s after the Second World War. [40] The evening dress and formal dinner dress that students wore continued to be very Victorian and solemn. One of the students stated, 'The experiences of formal dinner were probably very good for us in later life.' [29] These experiences were a part of the students' memories.

What was the reason for the colleges to maintain this tradition of dressing for dinner when it was gradually fading away in other areas? Considering that it was still practiced in elite country houses it might be viewed as a bid for social status. The comments of the dean of Sommerville College that have been shared above regarding maintaining the tradition are very suggestive. When the women's colleges began, one of the differences between them and the men's colleges, was that the latter had been functional for centuries and therefore had seen and followed numerous traditions. The customs related to dressing up were perhaps a means by which the women's colleges were looking at creating their own specific feminine traditions.

\section{Academic Dresses}

\subsection{Academic Dresses at Royal Holloway College}

Busser, who was at Royal Holloway College from 1908 to 1911 in 'My Memories of R.H.C.' described that 'academic dress, which was compulsory for chapel, was very useful. One's hair could be bundled up anyhow under the cap and the gown could cover a multitude of omissions below.' [18] The record of a Bedford Senior Student from $8^{\text {th }}$ March 1920 stated that wearing gowns became regulated. [41] The report of the Council for Session 1919 to 1920 mentioned that from 'January 1920, it has been made compulsory for students to wear academic dresses when attending lectures and at public functions.' [42]

At the Presentation of Degrees in 1923 it was instructed that the colours of the gown and hoods were to be decided according to the faculties. [43] According to the General Information in the Students Handbook for 1923 and 1924, academic dresses to be worn on all public occasions were to consist of caps and gowns, to be worn over a white dress or navy coat and skirt, black shoes, stockings, and white gloves. [42]

It is clear from the records of the students of Royal Holloway that they wore the academic dress when they went to the chapel on Sunday mornings.

Morris recalled that in the 1920 s, 'We were always changing our clothes. We changed for lectures in the morning' and had to our gowns for all the lectures. [27] It also seems that they hurried to change their clothing and wore the gown over them. Winter reminisced, 'The thing to do, as I was' told by my seniors, was 'to wake up at the 7.50 bell, and immediately to get ready' as we were 'allotted fifty minutes, don over all cap and gown', which could cover-up any inadequacies. [35]

At the University of London the custom of wearing academic gown was introduced at the same time as when they began conferring degrees to women students in the 1870s. Fifty years later, in the 1920s, at Royal Holloway, which was a college of the University of London, this gown was not only confined to the presentation of degrees but permitted at all occasions including while visiting the chapel, attending lectures, and during the break.

In an article that was published in the Illustrated London News on $6^{\text {th }}$ November 1937, a student was seen wearing an academic robe during a lecture (Figure 13). In the same article, some college girls were seen wearing academic gowns in rooms, the picture gallery and the library.

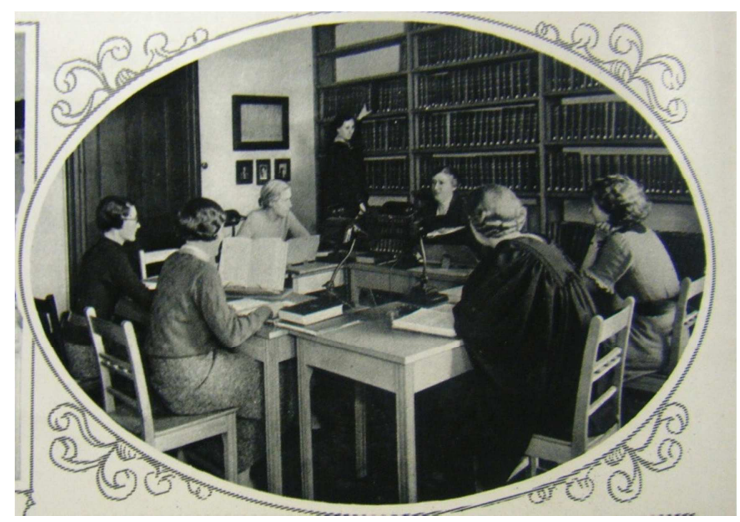

Figure 13. Illustrated London News (1937).

In the 1940s, the tradition to wear academic dresses could still be seen in the Royal Holloway and the girls also wore the gowns on Sundays. [44]

In 1955, one of the students said, 'we wore our gowns a lot more round the place. People don't wear gowns at all now. But we used to wear gowns to lectures and they used them' to protect themselves from the draught. [45] College girls were allowed to wear academic dresses from the end of the nineteenth century and wore them in almost all places till the first half of the twentieth century.

\subsection{Academic Dresses at Oxford}

\subsubsection{Lady Margaret Hall}

Women could wear academic gowns in the 1920s at the time when three women's colleges at Oxford began conferring women's degrees. At Lady Margaret Hall, the dresses of the women members were regulated for the degree conferring ceremony.

In the Ancient House of Congregation (Degree ceremony) the gown and hood were to be worn with the soft cap and the regulations regarding dark skirt, white blouse, black tie, black stockings, and black boots or shoes. This dress code 
had to be followed by those who are presenting or being presented the degree. [46]

Furthermore, students were requested to wear a dark coat for the degree ceremony and the women examiners were required to put on the same outfit. In 1928, the Lady Margaret Hall's jubilee was celebrated. An article in the Daily Telegraph in 1928 stated that, 'Gradually all women students began to take the full degree course in the hope that someday' they might get the degree. [47] It continued, 'They [Dame Emily Penrose and Miss Barbara Bradly] had to wait a quarter of a century, but the end was not in doubt. Degrees, like the suffrage, were won in the war, and Oxford with the coming of peace made full and graceful surrender.' [47]

Figure 14 is a photograph of the ceremony of 1928. Duchess of York can be seen in the middle of the photo and the principal is towards her left. In a letter to the principal written in July 1928, a student refers to the clothes worn by the Duchess.

The Duchess is truly as pretty and charming as she is supposed to be and was delightfully dressed in a sort of ecru coloured frock and hat and with lovely pearls. Her youth and charm were the perfect contrast to the beautiful old, old face and figure of our glorious Dame Elizabeth and the gourgeous D.C.L. [Doctor of Classical Literature] gown. [48]

Colourful gowns and hoods were seen at the tea party held after the ceremony. 'Over one thousand, I believe, and gowns and hoods of every gorgeous colour and M.A.s [masters of arts] and B.A.s [bachelors of arts] and undergraduate gowns too, of those just going down.' [48]

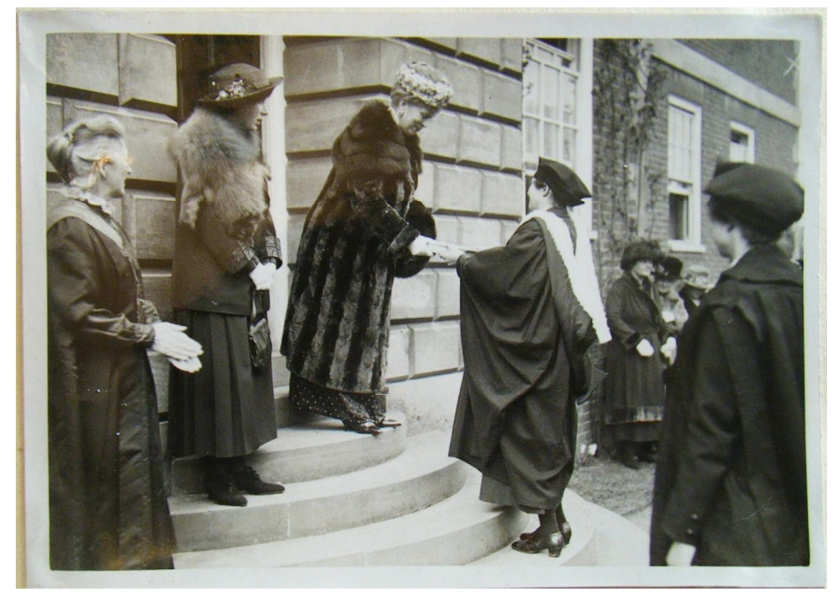

Figure 14. Ceremony, Lady Margaret Hall (1928).

\subsubsection{St. Hugh's}

The proctor proposed the references for the academic dress at St. Hugh's College in August 1920. According to a notice concerning the dress issued by the principal of St Hugh's College (in August 1920), 'Students are expected to wear the undergraduate gown and the cap of the approved pattern for lectures.' [49] In addition, there were requested to wear dresses for examinations and occasions and the shops from where these could be bought were also recommended. Many articles about this dress appeared in the newspapers at
Oxford when the college girls began to wear it. For instance, Oxford Times stated, 'The women student's gown is cut on much the same lines as that of the men, but the cap is larger and softer and exceedingly becoming.' [50] An article entitled 'Undergraduates' also appeared in the Daily Mail, one of the national newspapers on the $26^{\text {th }}$ October 1920.

Not only the long gown of the scholar, but even the short commoner's gown confers an air of charming dignity on a woman. However, the work of genius is the hat. It is not the cardboard square that the men have, but a flat pointed velvet 'tam'. [51]

'Tam' means a cap that is also known as the 'tam-o'-shanter'. It became fashionable among men in the nineteenth century and was later used by women and girls. [52]

When the Queen visited the Sheldonian Theatre in 1921, the academic dress was worn by college girls. In the article, 'Interest in Women's Education' which appeared in The Morning Post, on $12^{\text {th }}$ March 1921, it was mentioned 'The serried ranks of lady students in cap and gown emphasized the fact that it was a woman's day.' [53] Queen Mary wore 'doctor's gown and gold-tasseled cap' on this occasion. [53] At St. Hugh's College, the academic dress was introduced in the 1920s and they wore it for all occasions and ceremonies. Philippa who wore the academic dress in the 1930s while at St. Hugh's College said, 'I should like to record that I got great pleasure from wearing my gown'. [54] According to her, 'Belonging to the University meant a great deal to me and the feeling of' a part of 'medieval tradition gave me intense pleasure.' [54]

\subsubsection{St. Hilda's College}

St Hilda's also decided to wear academic dress in 1920. Figure 15 shows Winifred Penfold in 1920. This is the 'cap and (undergraduate) gown worn for the first time by women members of University.' [55] Figure 16 is a photograph of Petronella Frances Jones (née Snowball) with friends dressed for matriculation around the years 1921 to 1924 .

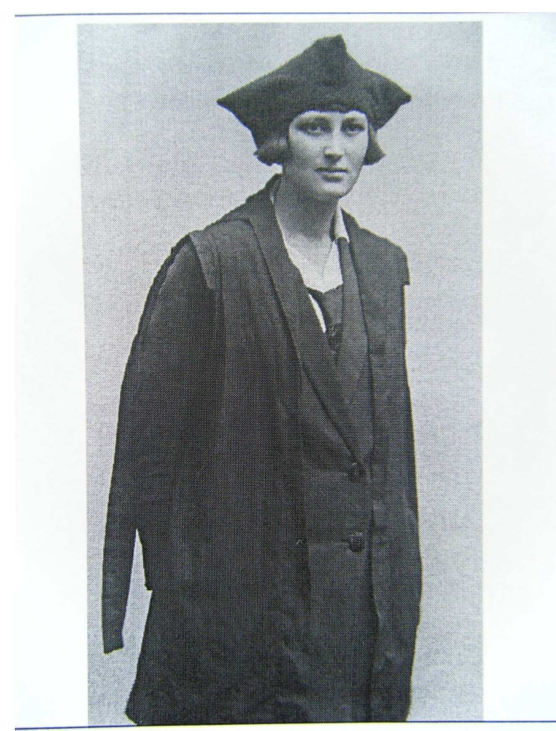

Figure 15. Winifred Penfold (1920). 


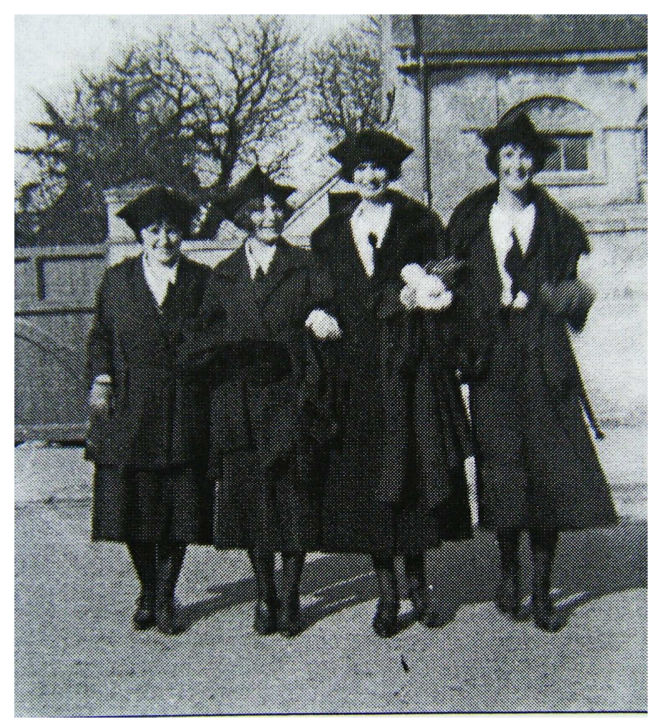

Figure 16. Petronella Frances Jones (née Snowball, 1921-1924).

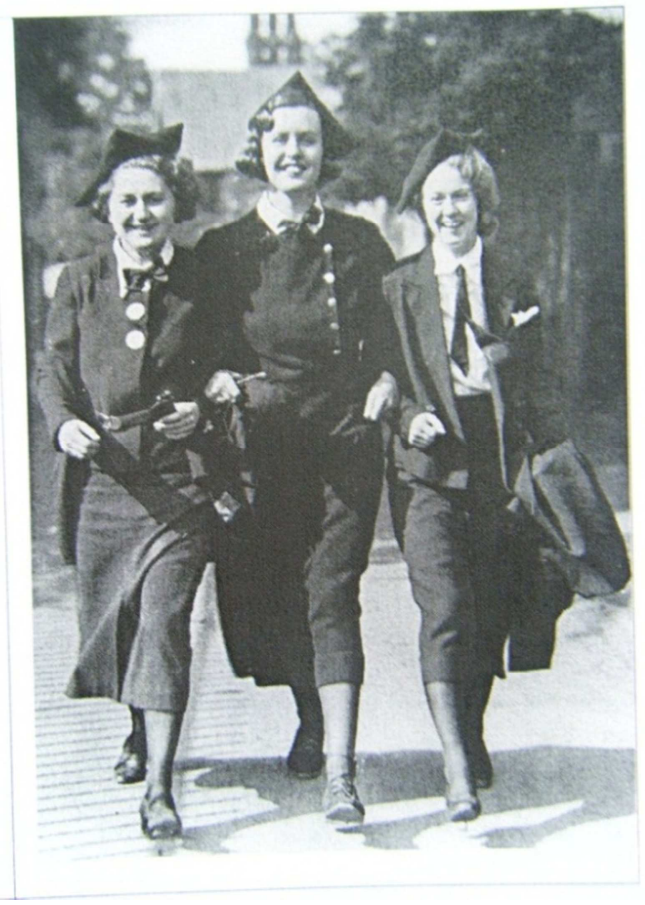

Figure 17. Mary Crampton Pym.

Barbara Mary Crampton Pym can be seen in the middle of the photo in Figure 17. She started studying at the college in 1931 and became a famous writer after graduating. [56] At St. Hilda's she was known as a fashion icon. Her friend on her right is holding her gown in her left hand. She has the same gown as the one that her seniors of Figure 16 wore ten years ago. The clothes of Pym and her friend to her right look very fashionable as they are wearing a jacket with buttons, a blouse with ribbons, and have curled hair and a cap.

Even the wartime academic gown was worn just like in other colleges in Oxford. 'Gown had to be worn to lecture and... But were excused in the labs.' [57]

\subsubsection{Somerville College}

In 1918 when Evelyn Irons was allowed to enter this college, she wrote to the principal saying that she felt proud to wear the gown but was unhappy because it 'looked embarrassingly new.' [58]

She also recalled that in the summer term in 1920, the Convocation of Somerville approved a statute under which, starting in October, "Women may be matriculated and admitted to degrees in the University." However, 'there was a catch in it. We would wear the gown, like the other member of the university, but not the mortarboard. Our headgear would be a soft, square black cap, like the one Erasmus has in the Holbein portrait.' [58] As Jane Robinson said, the soft black cap which they chose had 'dignity and perpetuated the distinction male and female'. [6]

Another student who studied at Sommerville from 1923 to 1926 and was pursued by Bulldogs mentioned that they had to wear gowns inside and outside of college and even at night.

In our days we always had to sing in and out of college and wear our gowns when out in the evening. We had to be in by 10 o' clock and I remember one night running at St. Giles' with my very best friend while being chased by Bulldogs, as we called the University Policemen. [59]

\section{Conclusion}

From the Victorian age to the eve of the Second World War, college girls attended the chapel in the morning and then went to morning lectures, in the afternoon they enjoyed sports and attended a coffee or tea party. In the evening, they participated in the formal dinners and before they slept they had small private cocoa parties in their rooms.

They often wore academic dresses and ordinary dresses for morning lectures and sports jacket or tunics over ordinary dresses in the afternoon. They changed into party dresses for the evening. Before they slept, pyjamas or clothes for a cocoa party were prepared for them.

College women tried to cope with 'double conformity' which has been discussed by one of the historians. 'To study better than the men' and 'to behave with marked decorum', that is, 'to be ladylike', cannot be achieved in conjunction. However, these girls managed to address this requirement by changing their clothes.

During the day they wore day dress, ordinary dress, or masculine dress, and changed into evening dresses for dinner. During the day, their clothes portrayed academic achievement and encouraged independence and self-developments by studying harder than the male students. In the evening, the same girls changed into evening dress and attempted 'to be ladylike' and 'to behave with decorum'.

Academic dresses fulfilled two requirements. On the one hand, they were worn to demonstrate professionalism and seriousness of purpose which college girls were attaining in their colleges for the future. They expected that degrees would ensure that they had the same opportunities as men in future.

On the other hand, they emphasised on their femininity. For example, the triangular soft cap, was worn to differentiate them from the male students who wore the mortarboard. In 
this manner, academic dresses played a role in maintaining traditional femininity.

By adding a cap to the academic clothing that portrayed both seriousness and femininity, they probably attempted to overcome the double bind, that is, a situation in which they were confronted with two irreconcilable demands, 'to study harder than male students' and 'to be ladylike.'

Moreover, the clothes played a positive role in displaying their identity. Clothing co-existed with their lives and altered based on the requirements. For example, when they participated in sports, they showed their belongingness with the teams, when ceremonies such as evening and tea parties were held, they wore special dresses to indicate a sense of participation in their community.

\section{References}

[1] Deborah Gorham, The Victorian Girl and the Feminine Ideal, Bloomington: Indiana University Press, 1985.

[2] Carol Dyhouse, No Distinction of Sex? Women in British Universities 1870-1939 London: UCL Press, 1995.

[3] Briony Kay, “'A New Kind of University Life': the Creation of a Feminine University Culture at Royal Holloway College 1886-1914," MA dissertation (RHUL 2005), unpublished.

[4] Sara Delamont, "The Contradictions in Ladies' Education", in Sara Delamont, and Duffin L., (eds.), The Nineteenth-Century Woman: Her Cultural and Physical World, London: Routledge, 1978, p. 140.

[5] Muriel C. Bradbrook, 'That Infidel Place': A Short History of Girton College 1869-1969, London: Chatto \& Windus, 1969, p. 6.

[6] Jane Robinson, Bluestockings: The Remarkable Story of the First Women to Fight for an Education, London: Penguin, 2010, pp. 133-138, 180.

[7] John Tosh, The Pursuit of History: Aims, Methods and New Direction in the Study of Modern History, Edinburgh: Pearson Educational Limited, 1984, rev., 2010, p. 98, 99.

[8] Lou Taylor, The Study of Dress History, Oxford: Alden Press, 2002, p. 243.

[9] Christopher Breward, The Hidden Consumer: Masculinities, Fashion and City Life, 1860-1914, Manchester: Manchester University Press, 1999, p. 18.

[10] Paul R. Deslandes, Oxbridge Men: British Masculinity and the Undergraduate Experience, 1850-1920, Bloomington: Indiana University Press, 2005, p. xi.

[11] Kathleen McCrone, Sport and the Physical Emancipation of English Women, 1870-1914, London: Routledge, 1988, p. 238.

[12] Unknown, Girton Diary references. List of references to Girton in the diary of Nova Knatchbull Hugesson, 22th November 1883, Girton College Reference (GCRF 4/2/1).

[13] Elizabeth Maclead (1881), A Day at Girton, Macleod Family Magazine, Girton College Reference (GCRF 4/1/24), p. 6, 8.

[14] Susan Macklin (1886), Extracts from the Diaries of Herbert Walter Macklin, Girton College Reference (GCRF 4/2/3).
[15] Robert Ross, Clothing: A Global History, Cambridge: Polity, 2008, pp. 103-105.

[16] Michelle Clewlow, Style and the Oxford Women, 24th September 1995 at the Annual Meeting of the Barbara Pym Society, St. Hilda's College, p. 2.

[17] Lady Dressmaker, Dress: in Season and Reason, The Girl's Own Paper, 24 Jan. 1885, p. 266.

[18] Busser (student, 1908 to 1911), My Memories of R.H.C., Reminiscences collected by Caroline Bingham A-B, RHC/RF/ $132 / 3,1985$.

[19] E. B. Moudy, Diary, Reminiscences Collected by Caroline Bingham B-D, RHC/ RF/132/6, 1985, p. 8.

[20] Winifred Evans (student, 1923 to 1925), Freda's Story, GCRF 4/1/14, p. 7.

[21] D. M. Sabine Pasley (student, 1919 to 1923), Success without Money in the Twenties, GCRF 4/1/1, p. 5.

[22] Miss A. A. Divine (student, 1921 to 25, principal's private secretary, 1942 to 1962), Gladys Morris (student, 1923 to 1926), RHC/RF/132/7, Reminiscences collected by Caroline Bingham, E-H, p. 2.

[23] W. Butbridge, Memories of R.H.C. (1926-27), Reminiscences collected by Caroline Bingham A-B, RHC/ RF/132/3, 1985, p. 4.

[24] Valerie Steele, The Corset: A Cultural History, New Haven: Yale University Press, 2001, p. 44, 56, 143-153, 165.

[25] Pearson Frances Beatrix Ruth (student, 1939-1942), Reminiscences, Senior Member Survey, 1991, 2nd sequence, St. Hilda's College Archive, pp. 221- 222.

[26] Mary Barham Johnson (student, 1914-1917), Reminiscences, Senior Member Survey, 1991, 2nd sequence, St. Hilda's College Archive, p. 1.

[27] Gradys Morris (student, 1923-1926) Reminiscences collected by Caroline Bingham, I-M, RHC/ RF/132/6, 1985, p. 1, 8.

[28] Doreen Yarwood, The Encyclopedia of World Costume, New York: Bonanza Books, 1978, p. 300.

[29] Joyce Pentelow (student, 1938-1942), Reminiscences collected by Caroline Bingham N-U, RHC/RF/132/7, 1985, p. 3.

[30] Alice Robinson, Reminiscences collected by Caroline Bingham, N-U, RHC/RF/132/7, 1985.

[31] Winifred Attlee (Muriel Attlee) (student, 1916-19) Reminiscences, Senior Member Survey, 1991, St. Hilda's College Archive, A4, p. 6.

[32] Joan Doren Curzon (student, 1917-1921), Reminiscences, Senior Member Survey, 1991, 2nd sequence, St. Hilda's College Archive, p. 1.

[33] P. M. Cooke, Patricia Garner, Social Life at RHC, 1931-5, Reminiscences collected by Caroline Bingham, N-U, RHC/RF/132/7, 1985, p. 3.

[34] Audrey Brodhurst (1931), Letters Home 1931-35 (transcripts), Somerville College Archive, p. 23, 29.

[35] F. M. Winter, Letters to Bingham, Reminiscences collected by Caroline Bingham, N-U, RHC/RF/132/8, 1985, p. 1, 4. 
[36] Mrs. Burt (student, 1939-41), Reminiscences collected by Caroline Bingham, A-B, RHC/RF/ 132/3, p. 1.

[37] Annice Szrajbman (A. M. Taylor, student, 1941-43), Reminiscences collected by Caroline Bingham N-U, 1985, $\mathrm{RHC} / \mathrm{RF} / 132 / 3$, p. 2.

[38] Mary Bayliss (née Provost, student, 1943-47), My Wartime Clothes at St Hilda's, Reminiscences, Senior Member Survey, 1991, 2nd sequence, St. Hilda's College Archive, p. 2.

[39] Irene Mary Davis (student, 1944-47), Reminiscences, Senior Member Survey, 1991, St. Hilda's College Archive, D1, p. 3.

[40] Mary Kennedy (student, 1950-54), Reminiscences collected by Caroline Bingham, N-U, RHC/RF/132/7, p. 6.

[41] The Bedford Senior Student Record, 8th March 1920, $\mathrm{BC} / \mathrm{AS} / 121 / 2$.

[42] Linna Bentley, Educating Women: A Pictorial History of Bedford College, University of London 1849-1985, Surry: Alma Publishers, 1991, p. 53.

[43] Papers Relating to the Presentation of Degrees (1923), Royal Holloway College Archive, RF/ PP 14/6, p. 4.

[44] Miss G, E. Harris (student, 1940-1943), Memories of a History Student, Reminiscences collected by Caroline Bingham, E-H, RHC/RF/132/5, p. 2.

[45] Caroline Bingham's interview with Ruth Miller (student 1955), RHC/RF/131/11, p. 2.

[46] L. R. Farnell (Vice Chancellor), Dress of Women Members of the University, Oct. 1928, Lady Margaret Hall College Archive.

[47] Mrs. W. L. Courtney, Women's University at Oxford, Lady
Margaret Hall Jubilee Celebration, A Graceful Surrender, Daily Telegraph (21th June 1928), n.p.

[48] Letter to the Principal, 1928, Lady Margaret Hall Archive, p. 4, 5 .

[49] E. F. Jourdain (Principal), Academic Dress, August, 1920, St. Hugh's College Archive.

[50] Daughter's of University, The Oxford Times (Friday, 8th October 1920), St. Hugh's College Archive, scrap.

[51] Undergraduates, Daily Mail (26th October 1920).

[52] R. Turner Wilcox, The Dictionary of Costume, New York: Scribner, 1969, p. 340

[53] Interest in Women' Education, The Morning Post (Saturday, 12 March 1921), St. Hugh's College Archive, scrap.

[54] Philippa Hesketh-Williams (student, 1933-1936), Reminiscences, 1930s, St. Hugh's College Archive, p. 2.

[55] Caption in the photographs: Personal Penfold W (St. Hilda's College Archive)

[56] Barbara Pym

(1913-1980) https://barbara-pym.org/about-barbara-pym-and-her-writings/ biography/ (accessed 12th May 2020).

[57] Hilary Joscleyne Eveleigh Christine (née Allen, 1941-1943), Reminiscences, Senior Member Survey, 1991, St. Hilda's College Archive, C2, pp. 4-5.

[58] Evelyn Irons, Letter to the Principle, Recollections of Sommerville, 1908, Sommerville College Archive, p. 10.

[59] Rachel Footman (Mrs Varcoe, student, 1923-26), Recollections of Sommerville, 1923, Sommerville College Archive. 